\title{
CYSTOISOSPORA CANIS NEMESÉRI, 1959 (SYN. ISOSPORA CANIS), INFECTIONS IN DOGS: CLINICAL SIGNS, PATHOGENESIS, AND REPRODUCIBLE CLINICAL DISEASE IN BEAGLE DOGS FED OOCYSTS
}

Author(s): Sheila M. Mitchell , Anne M. Zajac , Sam Charles , Robert B. Duncan , and David S. Lindsay Source: Journal of Parasitology, 93(2):345-352. 2007.

Published By: American Society of Parasitologists

DOI: http://dx.doi.org/10.1645/GE-1024R.1

URL: http://www.bioone.org/doi/full/10.1645/GE-1024R.1

BioOne (www.bioone.org) is a nonprofit, online aggregation of core research in the biological, ecological, and environmental sciences. BioOne provides a sustainable online platform for over 170 journals and books published by nonprofit societies, associations, museums, institutions, and presses.

Your use of this PDF, the BioOne Web site, and all posted and associated content indicates your acceptance of BioOne's Terms of Use, available at www.bioone.org/page/terms of use.

Usage of BioOne content is strictly limited to personal, educational, and non-commercial use. Commercial inquiries or rights and permissions requests should be directed to the individual publisher as copyright holder. 


\title{
CYSTOISOSPORA CANIS NEMESÉRI, 1959 (SYN. ISOSPORA CANIS), INFECTIONS IN DOGS: CLINICAL SIGNS, PATHOGENESIS, AND REPRODUCIBLE CLINICAL DISEASE IN BEAGLE DOGS FED OOCYSTS
}

\author{
Sheila M. Mitchell, Anne M. Zajac, Sam Charles, Robert B. Duncan, and David S. Lindsay $\dagger$ \\ Department of Biomedical Sciences and Pathobiology, Virginia Tech, 1410 Prices Fork Road, Blacksburg, Virginia $24061-0342$. \\ e-mail: lindsayd@vt.edu
}

\begin{abstract}
Canine intestinal coccidiosis is a cause of diarrhea in young dogs and dogs that are immunocompromised. Reports in the literature indicate that experimental reproduction of clinical coccidiosis with Cystoisospora canis (syn. Isospora canis) is difficult, and few studies have been done with C. canis. Experimental oral infections were attempted in 22, 6- to 8-wk-old female beagles with $5 \times 10^{4}(\mathrm{n}=2)$ or $1 \times 10^{5}(\mathrm{n}=20)$ sporulated $C$. canis oocysts. Diarrhea was observed in all inoculated dogs. Diarrhea began 2-3 days before oocyst excretion. Five of the 22 dogs were given an anticoccidial (sulfadimethoxine) because of their clinical signs. The mean prepatent period was 9.8 days (range, 9-11 days, $\mathrm{n}=22$ dogs), and the patent period was 8.9 days (range, $7-18$ days, $\mathrm{n}=20$ dogs). Two dogs exhibiting clinical coccidiosis were examined at necropsy 10 days after infection. Developmental stages of $C$. canis were present in cells in the lamina propria throughout the entire small intestine in both dogs. Microscopic lesions observed in both of these dogs were villous atrophy, dilation of lacteals, and hyperplasia of lymph nodes in Peyer's patches. Results of bacterial and viral examinations of these 2 dogs were negative, indicating that intestinal coccidiosis was the cause of the diarrhea. Our study indicates that $C$. canis can be a primary cause of diarrhea in young dogs.
\end{abstract}

Coccidia are common parasites of dogs worldwide. Dogs are hosts for Cystoisospora canis Nemeséri, 1959; Cystoisospora ohioensis Dubey, 1975; Cystoisospora burrowsi Trayser and Todd, 1978; and Cystoisospora neorivolta Dubey and Mahrt, 1978. In dogs, oocysts of C. canis can be definitively identified based on their structure in fecal samples because of their large size $(>33 \mu \mathrm{m})$ when compared with the oocysts of $C$. ohioensis, C. neorivolta, and C. burrowsi, which are structurally similar $(<30 \mu \mathrm{m})$ (Lindsay et al., 1997). The oocysts of these 3 similarsized coccidial species are often grouped together and termed C. ohioensis-like oocysts because detailed structural examinations and life-cycle studies are needed before a definitive diagnosis can be made. The life cycle and transmission of $C$. canis has been examined by several groups of researchers $(\mathrm{Ne}-$ meséri, 1960; Lepp and Todd, 1974, 1976; Dubey, 1975b, 1982; Hilali et al., 1979; Becker et al., 1981). The life cycles and transmission of C. ohioensis, C. neorivolta, and C. burrowsi, have also been examined (Dubey, 1975a, 1978a, 1978b; Dubey and Mahrt, 1978; Dubey and Mehlhorn, 1978; Dubey et al., 1978; Trayser and Todd, 1978; Becker et al., 1981; Rommel and Zielasko, 1981.).

There is controversy over the pathogenicity of $C$. canis and other Cystoisospora species occurring in dogs. Severe clinical disease was not produced in 25, 6-wk-old or 6, 8-wk-old dogs inoculated with $1-1.5 \times 10^{5} \mathrm{C}$. canis oocysts of an Illinois isolate of the parasite (Lepp and Todd, 1974). Nemeséri (1960) found that $5 \times 10^{3}$ oocysts of a Hungarian isolate of C. canis were not pathogenic for dogs, but an inoculum of 5 or $8 \times 10^{4}$ oocysts produced clinical coccidiosis. The present study was done to evaluate the pathogenicity of an isolate of $C$. canis obtained from pit bull puppies. Additionally, the oocysts of $C$. canis are redescribed, and additional information on the life cycle of C. canis is presented.

Received 29 August 2006; revised 23 October 2006; accepted 30 October 2006.

* Bayer HealthCare Animal Health, Shawnee Mission, Kansas 662010390.

$\dagger$ To whom correspondence should be addressed.

\section{MATERIALS AND METHODS}

\section{Source of oocysts}

Oocysts consistent with the structure of $C$. canis were identified in the feces of 2 littermate pit bull puppies, housed at the Montgomery County animal shelter in Blacksburg, Virginia. The pups were 1-2 mo of age. Feces were collected from these puppies 1 or 3 times/wk from 26 February 2004 through 24 March 2004. These oocysts were mixed in $2 \%(\mathrm{v} / \mathrm{v})$ sulfuric acid, filtered through 2 layers of cheesecloth, placed in a thin layer $(4-6 \mathrm{~mm})$ in $150-\mathrm{cm}^{2}$ tissue culture flasks with vented tops, and placed on a mechanical shaker for 4-6 days at room temperature. Oocysts were concentrated by flotation using Sheathers' sugar solution and stored at $4 \mathrm{C}$ in $2 \%$ sulfuric acid until used. Oocysts were washed free of sulfuric acid in sterile Hanks balanced salt solution (HBSS) by centrifugation before use in experimental infections.

\section{Dogs and fecal examinations}

Five experiments using 22 female beagles were conducted (Table I). Dogs were obtained at 6-8 wk of age (Covance, Cumberland, Virginia). Weights were obtained upon the dogs' arrival at our facilities and at weekly intervals thereafter. Fecal samples were examined using centrifugal flotation in Sheathers' sugar solution. Fecal samples were examined daily until dogs were orally infected (if feces were available). Samples were examined on days $-1,0$, and 1-29 for coccidial oocysts. Quantitative fecal oocyst counts using the McMaster method were done when a dog became positive for the $C$. canis oocyst (Tables II, III). Briefly, the McMaster method was conducted by mixing $2 \mathrm{~g}$ of feces with $28 \mathrm{ml}$ of Sheathers' sugar solution. Both sides of a McMaster counting slide were loaded with the mixture. Slides were allowed to sit for $5 \mathrm{~min}$, and then all oocysts present were counted. The total numbers of oocysts counted was determined by multiplying the number counted by 50 . No. 1 was used if the McMaster exam was negative, but the fecal float was positive.

\section{Clinical signs}

Clinical signs were recorded for each dog daily after clinical signs became apparent. Temperatures were obtained when dogs became clinically ill (Experiments 1-3) or at weekly intervals (Experiments 4-5). Fecal samples were scored daily (Table IV). Briefly, a score of $1=$ normal-formed feces; 2 = mixture of loose and formed; $3=$ completely loose but not liquid; and $4=$ liquid. A note was made whether blood or mucus was present.

Hematocrit and total protein values were examined weekly in dogs from Experiments 4 and 5.

\section{Experimental infections}

Experiments 1-5 used an inoculum dose of $1 \times 10^{5}$ sporulated $C$. canis oocysts, whereas Experiment 3 used an inoculum dose of $5 \times$ 
TABLE I. Experimental protocol for oral infection of dogs with sporulated oocysts of Cystoisospora canis, clinical signs, and prepatent and patent periods in days.

\begin{tabular}{|c|c|c|c|c|c|}
\hline Expt.* & Dog & $\begin{array}{l}\text { Dose of } \\
\text { Oocysts }\end{array}$ & $\begin{array}{l}\text { Clinical } \\
\text { signs }\end{array}$ & $\begin{array}{c}\text { Prepatent } \\
\text { period }\end{array}$ & $\begin{array}{l}\text { Patent } \\
\text { period }\end{array}$ \\
\hline 1 & $\mathrm{BAR} \dagger$ & $1 \times 10^{5}$ & Yes & 11 & 10 \\
\hline 1 & BAS $\uparrow+$ & $1 \times 10^{5}$ & Yes & 9 & 10 \\
\hline 2 & $\mathrm{AHC}$ & $1 \times 10^{5}$ & Yes & 10 & 5 \\
\hline 2 & $\mathrm{ALF} \dagger$ & $1 \times 10^{5}$ & Yes & 10 & 8 \\
\hline 2 & AHP & $1 \times 10^{5}$ & Yes & 10 & 8 \\
\hline 2 & AIZ1 & $1 \times 10^{5}$ & Yes & 10 & 8 \\
\hline 3 & BAG§ & $5 \times 10^{4}$ & Yes & 9 & 9 \\
\hline 3 & AXY§ & $5 \times 10^{4}$ & Yes & 10 & 7 \\
\hline 3 & BBH§ & $1 \times 10^{5}$ & Yes & 10 & 18 \\
\hline 3 & AYF\$ & $1 \times 10^{5}$ & Yes & 10 & 7 \\
\hline 4 & $\mathrm{ASF}+\S$ & $1 \times 10^{5}$ & Yes & 10 & 10 \\
\hline 4 & $\mathrm{ASH}$ & $1 \times 10^{5}$ & Yes & 10 & 11 \\
\hline 4 & ASI & $1 \times 10^{5}$ & Yes & 10 & 8 \\
\hline 4 & ASG§ & $1 \times 10^{5}$ & Yes & 10 & 8 \\
\hline 5 & AIY§ & $1 \times 10^{5}$ & Yes & 10 & 9 \\
\hline 5 & AJU & $1 \times 10^{5}$ & Yes & 10 & 8 \\
\hline 5 & AKA & $1 \times 10^{5}$ & Yes & 10 & 7 \\
\hline 5 & $\mathrm{AJY} \dagger$ & $1 \times 10^{5}$ & Yes & 10 & 7 \\
\hline 5 & AJA & $1 \times 10^{5}$ & Yes & 10 & 7 \\
\hline 5 & AJZ§ & $1 \times 10^{5}$ & Yes & 10 & 8 \\
\hline 5 & AJV & $1 \times 10^{5}$ & Yes & 9 & NA \\
\hline 5 & AIZ2 & $1 \times 10^{5}$ & Yes & 9 & NA \\
\hline
\end{tabular}

* Experiment number.

† Dog treated with sulfadimethoxine because of clinical coccidiosis.

† This dog was treated orally with $5 \mathrm{mg}$ prednisone daily 3 days before infection and then daily on days 1-6 and 8-12 after infection.

$\S$ Cystoisospora ohioensis-like oocysts observed in the feces of dog before experimental oral infection with $C$. canis oocysts.
$10^{4}$ sporulated $C$. canis oocysts in 2 of the 4 dogs in addition to the dose listed above in the remaining 2 dogs. Dogs were orally infected by mixing the appropriate amount of sporulated oocysts in commercial dog food (Hills Science Diet A DD, Topeka, Kansas). All dogs readily ate this mixture within 3-5 min, and none vomited the inoculum.

One dog (BAS) in Experiment 1 was treated orally with $5 \mathrm{mg}$ of prednisone daily for 3 days before infection and then daily on days 1-6 and 8-12 after infection (Table I). Results of Experiment 1 indicated that prednisone immunosuppression was not needed, and none of the other dogs was given this treatment. Dogs BAR, BAS, ALF, ASF, and AJY were treated with $25 \mathrm{mg} / \mathrm{kg}$ sulfadimethoxine (Pfizer Inc., Groton, Connecticut) for 2-3 days because of severe diarrhea (Table I).

\section{Pathogenicity and development study (Experiment 5)}

Experiment 5, using 8 dogs, was designed to determine the role of C. canis in the pathogenicity of diarrhea observed in the infected dogs and to rule out other causes, such as bacteria and viruses. The sporulated oocyst inoculum was treated with $50 \%$ v/v bleach solution for $5 \mathrm{~min}$ on an ice bath and then washed by centrifugation in cold sterile HBSS until the smell of bleach was no longer present. This inoculum was then streaked onto blood agar and TSA agar to detect bacteria that may have survived bleach treatment. This inoculum was used to infect 8 beagles.

Two dogs (AJV and AIZ-2) were killed 10 days postinoculation (PI). A board-certified pathologist (R.B.D) conducted the necropsy. Intestinal tissues were collected for bacteriological culture and histological examination. Additional tissues collected for histology only and fixed in $10 \%$ neutral buffered formalin solution were mesenteric lymph nodes, liver, and spleen. Formalin-fixed tissues were embedded in paraffin, sectioned at $6 \mu \mathrm{m}$, and stained with hematoxylin and eosin. Feces were collected for virology and examined by transmission electron microscopy (TEM) after negative staining at the Texas Veterinary Medical Diagnostic Laboratory, College Station, Texas. Additionally, portions of ileum were fixed in $3 \%(\mathrm{v} / \mathrm{v})$ glutaraldehyde in phosphate buffer (PBS, $\mathrm{pH}$ 7.4). Tissues were postfixed in $1 \%(\mathrm{w} / \mathrm{v})$ osmium tetroxide in 0.1 $\mathrm{M}$ phosphate buffer, dehydrated in a series of ethanols, passed through 2 changes of propylene oxide, and embedded in Poly/Bed 812 resin (Polysciences Inc., Warrington, Pennsylvania). Thin sections were stained with uranyl acetate and lead citrate and examined with a Zeiss

TABLE II. Daily McMaster's oocysts counts per gram of feces per dog (days 8-17).

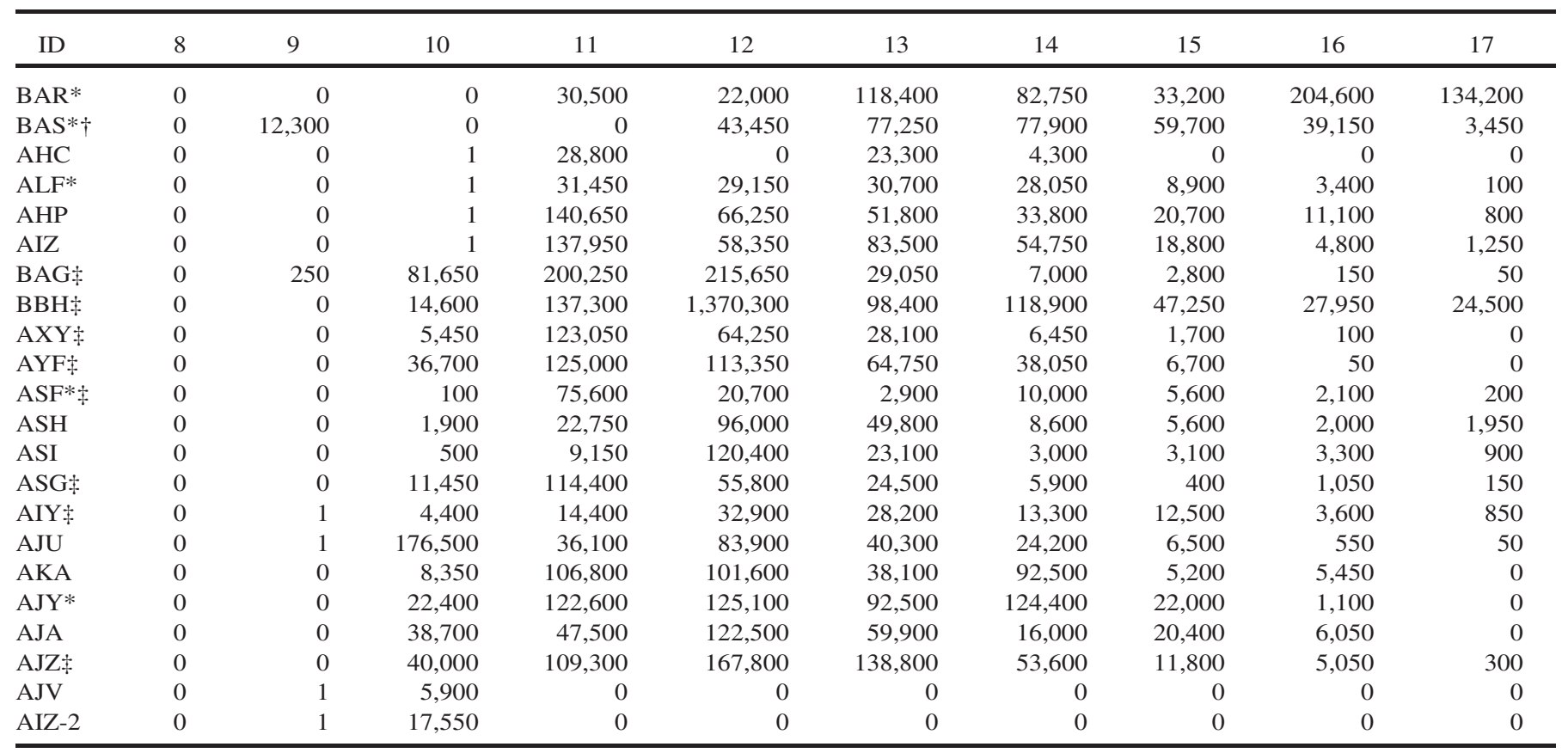

* Dog treated with sulfadimethoxine because of clinical coccidiosis.

$\dagger$ This dog was treated orally with $5 \mathrm{mg}$ prednisone daily 3 days before infection and then daily on days $1-6$ and $8-12$ after infection.

* Cystoisospora ohioensis-like oocysts observed in the feces of dog before experimental oral infection with $C$. canis oocysts. 
TABLE III. Daily McMaster's oocysts counts per gram of feces per dog (days 18-27).

\begin{tabular}{|c|c|c|c|c|c|c|c|c|c|c|}
\hline ID & 18 & 19 & 20 & 21 & 22 & 23 & 24 & 25 & 26 & 27 \\
\hline BAS $* \dagger$ & 350 & 0 & 0 & 0 & 0 & 0 & 0 & 0 & 0 & 0 \\
\hline $\mathrm{ALF}^{*}$ & 0 & 0 & 0 & 0 & 0 & 0 & 0 & 650 & 1,250 & 600 \\
\hline AHP & 0 & 0 & 0 & 0 & 0 & 0 & 0 & 0 & 0 & 0 \\
\hline AIZ & 0 & 0 & 0 & 0 & 0 & 0 & 50 & 0 & 0 & 0 \\
\hline AXY & 0 & 0 & 0 & 0 & 0 & 0 & 0 & 0 & 0 & 0 \\
\hline AYF & 0 & 0 & 0 & 0 & 0 & 0 & 0 & 0 & 0 & 0 \\
\hline ASF* $*$ & 850 & 250 & 0 & 0 & 0 & 0 & 0 & 0 & 0 & 0 \\
\hline $\mathrm{ASH}$ & $1,150,200$ & 200 & 50 & 0 & 0 & 0 & 0 & 0 & 0 & 0 \\
\hline ASI & 0 & 0 & 0 & 0 & 0 & 0 & 0 & 0 & 0 & 0 \\
\hline ASG $\neq$ & 0 & 0 & 0 & 0 & 0 & 0 & 0 & 0 & 0 & 0 \\
\hline $\mathrm{AJZ} \ddagger$ & 0 & 0 & 0 & 0 & 0 & 0 & 0 & 0 & 0 & 0 \\
\hline AJV & 0 & 0 & 0 & 0 & 0 & 0 & 0 & 0 & 0 & 0 \\
\hline AIZ-2 & 0 & 0 & 0 & 0 & 0 & 0 & 0 & 0 & 0 & 0 \\
\hline
\end{tabular}

* Dog treated with sulfadimethoxine because of clinical coccidiosis.

$\dagger$ This dog was treated orally with $5 \mathrm{mg}$ prednisone daily 3 days before infection and then daily on days $1-6$ and $8-12$ after infection.

$\ddagger$ Cystoisospora ohioensis-like oocysts observed in the feces of dog before experimental oral infection with C. canis oocysts.

TABLE IV. Daily fecal scores* postinoculation (PI) (dogs BAR-AYF).

\begin{tabular}{|c|c|c|c|c|c|c|c|c|c|c|}
\hline Days PI & $\mathrm{BAR} \dagger$ & BAS $†+$ & $\mathrm{AHC}$ & $\mathrm{ALF} \dagger$ & AHP & AIZ & BAG & BBH§ & AXY§ & AYF\$ \\
\hline-1 & 1 & 1 & 2 & 1 & 1 & 1 & 1 & 1 & 1 & 1 \\
\hline 0 & 2 & 1 & 2 & 1 & 1 & 1 & 1 & 1 & 1 & 1 \\
\hline 1 & 2 & 1 & 2 & 2 & 1 & 1 & 1 & 1 & 1 & 2 \\
\hline 2 & 2 & 1 & 2 & 2 & 1 & 1 & 1 & 1 & 1 & 1 \\
\hline 3 & 1 & 1 & 1 & 2 & 1 & 1 & 1 & 1 & 1 & 1 \\
\hline 4 & 1 & 1 & 2 & 2 & 2 & 2 & 1 & 1 & 1 & 1 \\
\hline 5 & 2 & 1 & 2 & 2 & 2 & 2 & 1 & 2 & 1 & 1 \\
\hline 6 & 2 & 3 & 1 & 1 & 2 & 2 & 1 & 2 & 1 & 2 \\
\hline 7 & 1 & 2 & 1 & 1 & 2 & 1 & 1 & 2 & 1 & 2 \\
\hline 8 & 1 & 1 & 4 & 4 & 2 & 1 & 2 & 2 & 2 & 2 \\
\hline 9 & 4 & 3 & 4 & 4 & 3 & 3 & 3 & 3 & 2 & 1 \\
\hline 10 & 4 & 4 & 4 & 4 & 4 & 4 & 4 & 2 & 2 & 3 \\
\hline 11 & 4 & 4 & 4 & 4 & 4 & 3 & 3 & 2 & 2 & 3 \\
\hline 12 & 4 & 2 & 4 & 4 & 4 & 2 & 4 & 1 & 2 & 3 \\
\hline 13 & 4 & 2 & 3 & 4 & 4 & 3 & 4 & 3 & 3 & 3 \\
\hline 14 & 4 & 2 & 3 & 4 & 4 & 2 & 2 & 2 & 1 & 2 \\
\hline 15 & 3 & 4 & 4 & 4 & 4 & 3 & 2 & 2 & 1 & 2 \\
\hline 16 & 4 & 4 & 3 & 3 & 3 & 3 & 2 & 2 & 1 & 2 \\
\hline 17 & 4 & 4 & 3 & 3 & 3 & 3 & 2 & 2 & 1 & 1 \\
\hline 18 & 3 & 3 & 2 & 2 & 2 & 2 & 1 & 1 & 1 & 1 \\
\hline 19 & 3 & 2 & 1 & 1 & 2 & 1 & 1 & 1 & 1 & 1 \\
\hline 20 & 2 & 2 & 2 & 2 & 2 & 1 & 1 & 1 & 1 & 1 \\
\hline 21 & 2 & 2 & 2 & 2 & 2 & 1 & 1 & 1 & 1 & 1 \\
\hline 22 & 2 & 2 & 1 & 2 & 1 & 1 & 1 & 1 & 1 & 1 \\
\hline 23 & 3 & 2 & 1 & 2 & 1 & 1 & 1 & 1 & 1 & 1 \\
\hline 24 & 2 & 1 & 1 & 2 & 2 & 1 & 1 & 1 & 1 & 1 \\
\hline
\end{tabular}

* A score of $1=$ normal-formed feces; $2=$ mixture of loose and formed; $3=$ completely loose but not liquid; and $4=$ liquid.

$\dagger$ Dog treated with sulfadimethoxine because of clinical coccidiosis.

+ This dog was treated orally with $5 \mathrm{mg}$ prednisone daily 3 days before infection and then daily on days $1-6$ and 8-12 after infection.

$\S$ Cystoisospora ohioensis-like oocysts observed in the feces of dog before experimental oral infection with C. canis oocysts. 
TABLE V. Daily fecal scores* postinoculation (PI) (dogs ASF-AIZ-2).

\begin{tabular}{|c|c|c|c|c|c|c|c|c|c|c|c|c|}
\hline Days PI & ASF $† \ddagger$ & ASH & ASI & ASG & AIY & AJU & AKA & $\mathrm{AJY} \dagger$ & AJA & $\mathrm{AJZ} \ddagger$ & AJV & AIZ-2 \\
\hline 0 & 1 & 1 & 1 & 1 & 2 & 1 & 1 & 1 & 1 & 1 & 1 & 1 \\
\hline 2 & 1 & 1 & 1 & 1 & 3 & 2 & 2 & 3 & 3 & 3 & 3 & 2 \\
\hline 3 & 1 & 1 & 1 & 1 & 3 & 3 & 1 & 3 & 1 & 3 & 3 & 3 \\
\hline 4 & 1 & 1 & 1 & 1 & 3 & 2 & 2 & 2 & 2 & 3 & 3 & 2 \\
\hline 7 & 1 & 1 & 1 & 2 & 4 & 2 & 1 & 1 & 1 & 2 & 2 & 1 \\
\hline 8 & 1 & 1 & 2 & 2 & NA§ & 4 & 2 & 2 & 1 & 3 & 3 & 3 \\
\hline 9 & 3 & 2 & 1 & 4 & 4 & 4 & 4 & 4 & 4 & 4 & 4 & 4 \\
\hline 10 & 4 & 4 & 4 & 4 & 4 & 4 & 4 & 4 & 4 & 4 & 4 & 4 \\
\hline 11 & 4 & 4 & 4 & 4 & 4 & 4 & 4 & 4 & 4 & 4 & NA & NA \\
\hline 12 & 4 & 4 & 4 & 4 & 4 & 4 & 2 & 4 & 4 & 4 & NA & NA \\
\hline 18 & 1 & 1 & 1 & 1 & 2 & 1 & 1 & 3 & 3 & 2 & NA & NA \\
\hline 19 & 1 & 1 & 1 & NA & 3 & 3 & 2 & 3 & 3 & 3 & NA & NA \\
\hline 20 & 1 & 1 & 2 & 1 & 2 & 3 & 1 & 1 & 2 & 1 & NA & NA \\
\hline 21 & 1 & 1 & 1 & 1 & 1 & 1 & 2 & 1 & 2 & 1 & NA & NA \\
\hline 22 & 2 & 1 & 1 & 2 & 1 & 1 & 1 & 1 & 2 & 1 & NA & NA \\
\hline 23 & 1 & 1 & 1 & 1 & 3 & 1 & 1 & 1 & 2 & 2 & NA & NA \\
\hline 24 & 1 & 1 & 1 & 1 & 1 & 2 & 1 & 1 & 1 & 1 & NA & NA \\
\hline
\end{tabular}

* A score of $1=$ normal-formed feces; $2=$ mixture of loose and formed; $3=$ completely loose but not liquid; and $4=$ liquid.

$\dagger$ Dog treated with sulfadimethoxine because of clinical coccidiosis.

$\mp$ Cystoisospora ohioensis-like oocysts observed in the feces of dog before experimental oral infection with $C$. canis oocysts.

$\S$ Not applicable because no sample was obtained that day postinoculation.

10CA TEM operating at $60 \mathrm{kV}$. Digital images were captured using an ATM camera system (Advanced Microscopy Techniques Corp., Danvers, Massachusetts).

Thick sections of resin-embedded tissues were stained with methylene blue-Azure II-Basic fuchsin triple stain (Hayat, 1989) and mounted on glass slides for observation with light microscopy.

\section{Immunohistochemistry}

Immunohistochemistry was done to determine whether developmental stages of $C$. canis contained cross-reactive antigens to Neospora caninum, Toxoplasma gondii, or Sarcocystis neurona. Parasite-specific antisera were made in rabbits and used at dilutions of 1:500 and 1: 1,000. Paraffin-embedded tissue sections of $C$. canis-infected ileum were cut at $6 \mu \mathrm{m}$, mounted on glass slides, and used for immunohistochemical examinations using the avidin-biotin immunoperoxidase complex (ABC) test, as previously described by Lindsay and Dubey (1989). Positive controls for parasite cross-reactivity were tissue sections containing developmental stages of $T$. gondii, $N$. caninum, or $S$. neurona.

\section{Redescription of $C$. canis}

Sporulated oocysts from pit bull puppies were examined using an Olympus BX60 microscope equipped with differential contrast optics and a digital camera. Measurements were obtained from 25 oocysts using oil emersion and a calibrated ocular micrometer.

\section{RESULTS}

Cystoisospora ohioensis-like oocysts were observed in the feces of dogs in Experiment 3 (4 of $4 \mathrm{dogs}$ ), Experiment 4 (2 of $4 \mathrm{dogs}$ ), and Experiment 5 ( 2 of $8 \mathrm{dogs}$ ) before infection with $I$. canis oocysts (Tables I-III). Clinical signs were not as- sociated with the presence of these $C$. ohioensis-like oocysts All dogs that excreted $C$. ohioensis-like oocysts were susceptible to clinical coccidiosis when fed $C$. canis oocysts orally (Table I). The 2 dogs (AJV and AIZ2) used in Experiment 5 for histology and pathology studies never excreted $C$. ohioensis-like oocysts, and that was a selection criterion for their use in the studies. The $C$. canis oocyst counts for the dogs in Experiments $1-5$ are presented in Tables II and III.

\section{Clinical signs}

Clinical coccidiosis was induced in all dogs in Experiments 1-5 (Table I). Fecal scores are presented in Tables IV-V. Fecal scores of 3 or 4 , indicating severe diarrhea, were usually seen 2-3 days before oocyst excretion. Clinical signs were consistent with canine coccidiosis and included watery or bloody diarrhea, anorexia, weight loss, vomiting, and lethargy. Increased rectal temperatures were also noted in most dogs. Hematocrit and total protein values obtained from dogs in Experiments 4 and 5 were within normal ranges (37-55\% hematocrit; $5.2-7.8 \mathrm{~g} / \mathrm{dl}$ total protein) for dogs. Total weight gains for dogs ranged from 0.2 to $3.0 \mathrm{~kg}$ (Table VI).

All dogs excreted $C$. canis oocysts. The mean prepatent period was 9.8 days (range, 9-11 days, $\mathrm{n}=22$ dogs), and the patent period was 8.9 days (range, $7-18, \mathrm{n}=20 \mathrm{dogs}$ ).

\section{Pathogenicity and development}

Results of histopathological examination of small intestine documented asexual stages and sexual stages of $C$. canis within 
TABLE VI. Beginning and ending weights of dogs in kilograms.

\begin{tabular}{|c|c|c|c|c|c|}
\hline Expt.* & Dog & Oocysts & Beginning & Ending & Total gain \\
\hline 1 & $\mathrm{BAR}+$ & $1 \times 10^{5}$ & 2.5 & 3.8 & 1.3 \\
\hline 1 & $\mathrm{BAS}+\ddagger$ & $1 \times 10^{5}$ & 2.8 & 4.3 & 1.5 \\
\hline 2 & $\mathrm{AHC}$ & $1 \times 10^{5}$ & 2.6 & 2.8 & 0.2 \\
\hline 2 & $\mathrm{ALF} \dagger$ & $1 \times 10^{5}$ & 2.0 & 3.1 & 1.1 \\
\hline 2 & AHP & $1 \times 10^{5}$ & 2.8 & 3.8 & 1.0 \\
\hline 2 & AIZ & $1 \times 10^{5}$ & 1.8 & 2.7 & 0.9 \\
\hline 3 & BAG $§$ & $5 \times 10^{4}$ & 1.6 & 4.3 & 2.7 \\
\hline 3 & BBH§ & $5 \times 10^{4}$ & 1.5 & 4.5 & 3.0 \\
\hline 3 & AXY§ & $1 \times 10^{5}$ & 1.9 & 4.7 & 2.8 \\
\hline 3 & AYF§ & $1 \times 10^{5}$ & 1.5 & 4.5 & 3.0 \\
\hline 4 & $\mathrm{ASF} \uparrow \S$ & $1 \times 10^{5}$ & 1.0 & 2.5 & 1.5 \\
\hline 4 & $\mathrm{ASH}$ & $1 \times 10^{5}$ & 1.1 & 2.8 & 1.7 \\
\hline 4 & ASI & $1 \times 10^{5}$ & 1.2 & 3.0 & 1.8 \\
\hline 4 & ASG $§$ & $1 \times 10^{5}$ & 1.0 & 2.5 & 1.5 \\
\hline 5 & AIY§ & $1 \times 10^{5}$ & 1.5 & 3.0 & 1.5 \\
\hline 5 & AJU & $1 \times 10^{5}$ & 1.7 & 2.7 & 1.0 \\
\hline 5 & AKA & $1 \times 10^{5}$ & 2.0 & 3.2 & 1.2 \\
\hline 5 & $\mathrm{AJY} \dagger$ & $1 \times 10^{5}$ & 1.7 & 2.7 & 1.0 \\
\hline 5 & AJA & $1 \times 10^{5}$ & 2.0 & 3.0 & 1.0 \\
\hline 5 & $\mathrm{AJZ} \S$ & $1 \times 10^{5}$ & 1.8 & 3.2 & 1.4 \\
\hline 5 & AJV $\|$ & $1 \times 10^{5}$ & 2.2 & 2.4 & 0.2 \\
\hline 5 & AIZ-2\| & $1 \times 10^{5}$ & 1.7 & 2.0 & 0.3 \\
\hline
\end{tabular}

* Experiment number.

$\dagger$ Dog treated with sulfadimethoxine because of clinical coccidiosis.

$\ddagger$ This dog was treated orally with $5 \mathrm{mg}$ prednisone daily 3 days before infection and then daily on days 1-6 and 8-12 after infection.

$\S$ Cystoisospora ohioensis-like oocysts observed in the feces of dog before experimental oral infection with $C$. canis oocysts.

\| Dog was killed and examined at necropsy.

the subepithelial lamina propria of intestinal villi (Figs. 1-4). There was mild villous atrophy; moderate, diffuse villous epithelial cell attenuation; moderate crypt epithelial cell hyperplasia; occasional widely scattered, mildly dilated lacteals; and marked lymphoid hyperplasia of the Peyer's patches (Fig. 5). Occasional crypts contained a few eosinophils, polymorphonuclear leukocytes, and necrotic epithelial cells. Rare sexual stages of $C$. canis were present in the colon. Extraintestinal stages of $C$. canis were not detected in the mesenteric lymph nodes, but there was moderate-to-marked lymphoid hyperplasia, mild sinus histiocytosis, and occasional scattered foci of neutrophils and eosinophils.

No bacterial growth was observed on the blood agar or TSA agar plates after 3 days of incubation with sterilized oocysts mixture used to infect dogs. No bacterial pathogens were isolated from the intestines of the 2 dogs killed and examined at necropsy. No viruses were detected by electron microscopy in the feces from these 2 dogs.

Schizonts, merozoites, macrogamonts, microgamonts, and oocysts were present in all sections of small intestines (Figs. 1-4) from both dogs. Developmental stages were located in a parasitophorous vacuole in host cells that were in the lamina propria. Different developmental stages appeared to be in the same host cell (Fig. 3). Immature schizonts and mature merozoites could also been seen in the same cell. Occasionally, macrogamonts and microgamonts were seen in the same host cell. Light microscopic observations on asexual stages occupying the same host cell were validated by examinations using TEM.

\section{Immunohistochemistry}

Developmental stages of $C$. canis did not react with antibodies to $T$. gondii, $N$. caninum, or $S$. neurona.

\section{REDESCRIPTION}

\section{Cystoisospora canis}

Diagnosis: Oocysts ovoid. Micropyle absent; oocyst residuum absent. Sporulated oocysts measure $37.2 \pm 1.0$ by $29.5 \pm 1.2 \mu \mathrm{m}$ (35-39 by $27-32 \mu \mathrm{m}, \mathrm{n}=25)$; length to width ratio $1.3 \pm 0.06(1.16-1.38, \mathrm{n}=$ 25). Two sporocysts present in each oocyst; sporocysts ellipsoidal, Stieda and substieda bodies absent, sporocyst residuum present, composed of a compact spherical mass or dispersed granules. Sporocysts measure $21.2 \pm 0.9$ by $16.3 \pm 0.1 \mu \mathrm{m}(19-23$ by $15-18 \mu \mathrm{m}, \mathrm{n}=25)$; length to width ratio $1.3 \pm 0.08(1.17-1.47, \mathrm{n}=25)$. Four sporozoites in each sporocyst.

\section{Taxonomic summary}

Type host: Domestic dog, Canis familiaris.

Other hosts: Coyotes, Canis latrans, are experimental (Loveless and Anderson, 1975, Dubey, 1982; Dunbar and Foreyt, 1985) and natural hosts (Dubey, Fayer et al., 1978).

Paratenic hosts: Mice, cats, dogs, swine, sheep, water buffalos, and camels (Dubey, 1975b, Hilali et al., 1992, 1995; Zayed and El-Ghaysh, 1998). These studies are based on feeding tissues of naturally or experimentally infected animals and finding oocysts of $C$. canis in canine feces after feeding of host tissues.

Location in host: Inside of host cells, within the lamina propria of the duodenum, jejunum, and ileum of the small intestine and rarely the colon.

Prepatent period: From 9 to 11 days (Nemeséri, 1960; Lepp and Todd, 1974; present study) if oocysts are used as inoculum. The prepatent period is 8-9 days in dogs fed C. canis-infected mice (Dubey, 1975b).

Patent period: Either 4 wk (Nemeséri, 1960) or 7-15 days (present study).

Sporulation time: Sporulation is complete in $48 \mathrm{hr}$ at $20 \mathrm{C}$ and $16 \mathrm{hr}$ at 30 or $35 \mathrm{C}$ (Lepp and Todd, 1976).

Material deposited: A phototype (see Bandoni and Duszynski, 1988) of sporulated oocysts is deposited in the U.S. National Parasite Collection (USNPC), Beltsville, Maryland. USNPC no. 097291.00.

\section{Remarks}

Amorphous inclusions were present between the sporont and oocyst wall of many unsporulated $C$. canis oocysts. These inclusions have been observed in unsporulated Cystoisospora suis oocysts from pigs (Biester and Murray, 1934; Lindsay et al., 1980, 1982) and unsporulated Cystoisospora rivolta oocysts from cats (Dubey, 1979). This material is not present in fully sporulated oocysts of these Cystoisospora species.

\section{DISCUSSION}

Intestinal coccidial infections in naturally infected dogs have been examined in many countries (Dubey, Weisbrode et al., 1978; Boch et al., 1981; Correa et al., 1983; Kirkpatrick and Dubey, 1987; Penzhorn et al., 1992; Daugschies et al., 2000; Junker and Houwers, 2000). It is difficult to attribute intestinal disease to coccidia unless other pathogens are ruled out in a thorough search for disease-causing agents (Lindsay et al., 1997). Most studies rely only on clinical signs and do not examine tissues for lesions or other pathogenic agents. Penzhorn et al. (1992) studied a commercial German Shepherd breeding kennel in South Africa and found Cystoisospora sp. oocysts in the feces of dogs with diarrhea, some of which were also hemorrhaging. These authors were not able to demonstrate canine pathogenic bacteria or viruses in the feces of these dogs (Penzhorn et al., 1992). They were not able to link oocyst excretion 

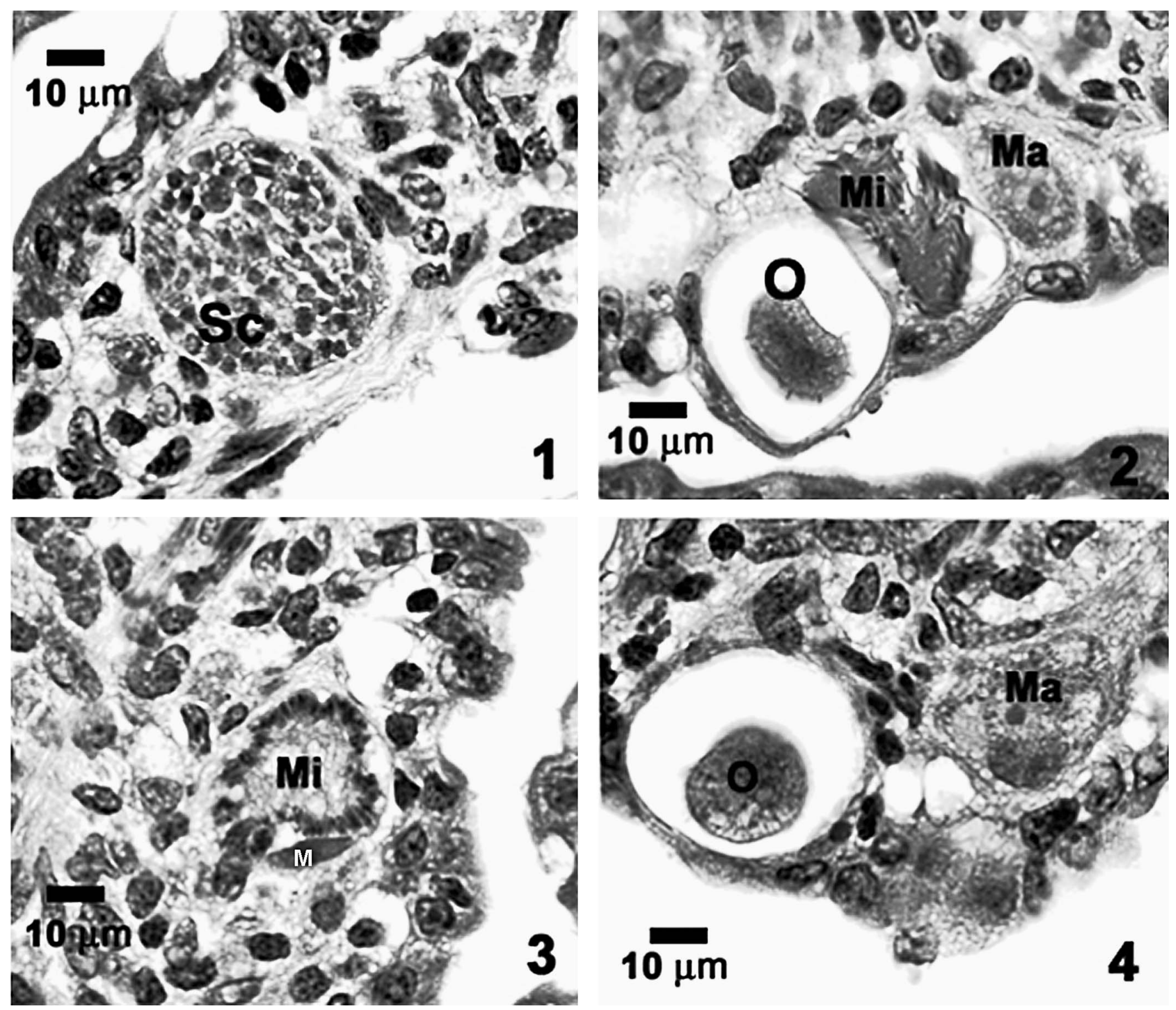

FIGURES 1-4. Hematoxylin and eosin stained histological sections of the ileum of dog AIZ infected with $1 \times 10^{5}$ Cystoisospora canis oocysts 10 days previously and demonstrating developmental stages in the intestinal lamina propria. (1) A mature schizont (Sc) containing numerous merozoites is located in a host cell in the lamina propria. (2) Several sexual stages including an oocyst (O), a mature microgamont (Mi) with microgametes, and a macrogamont (Ma) are present in this section. (3) An immature microgamont (Mi) that appears to be in the same host cell as a merozoite (M). The infected cell is in the lamina propria. (4) An oocyst with a contracted sporont (O) and a macrogamont (Ma) in the lamina propria.

by bitches to coccidial infections in their puppies. Daugschies et al. (2000) reported that natural Cystoisospora sp. infections were regularly found in 3- to 4-wk-old pups in dog-breeding facilities and that they were not always associated with diarrhea.

Experimental studies on the pathogenicity of canine coccidia are few, and they often conflict each other. Dubey (1978b) found that $5 \times 10^{5} \mathrm{C}$. ohioensis oocysts (administered as $1 \times$ $10^{6}$ sporocysts in the original paper) caused diarrhea in experimentally infected 7-day-old pups but not weaned pups or young dogs. Microscopic changes associated with $C$. ohioensis infection included villous atrophy, necrosis of apical enterocytes, and cryptitis (Dubey, 1978b). Daugschies et al. (2000) reported puppies (age not given) experimentally infected with 4 $\times 10^{4}$ oocysts of the $C$. ohioensis group developed catarrhalto-hemorrhagic diarrhea. Little is known about the pathogenicity of C. neorivolta (Mahrt, 1967; Dubey and Mahrt, 1978) or C. burrowsi (Trayser and Todd, 1978; Rommel and Zielasko, 1981).

Levine and Ivens (1981) suggested that strain differences in pathogenicity of $C$. canis could be present in dogs. Nemeséri (1960) found that $5 \times 10^{3}$ oocysts of a Hungarian isolate of $C$. canis were not pathogenic for dogs, but an inoculum of 5 or 8 $\times 10^{4}$ oocysts produced clinical coccidiosis. In contrast, severe clinical disease was not produced in 25 , 6-wk-old or 6,8 -wkold pups inoculated with $1-1.5 \times 10^{5} \mathrm{C}$. canis oocysts (Lepp and Todd, 1974) isolated in dogs from Illinois. The pathoge- 


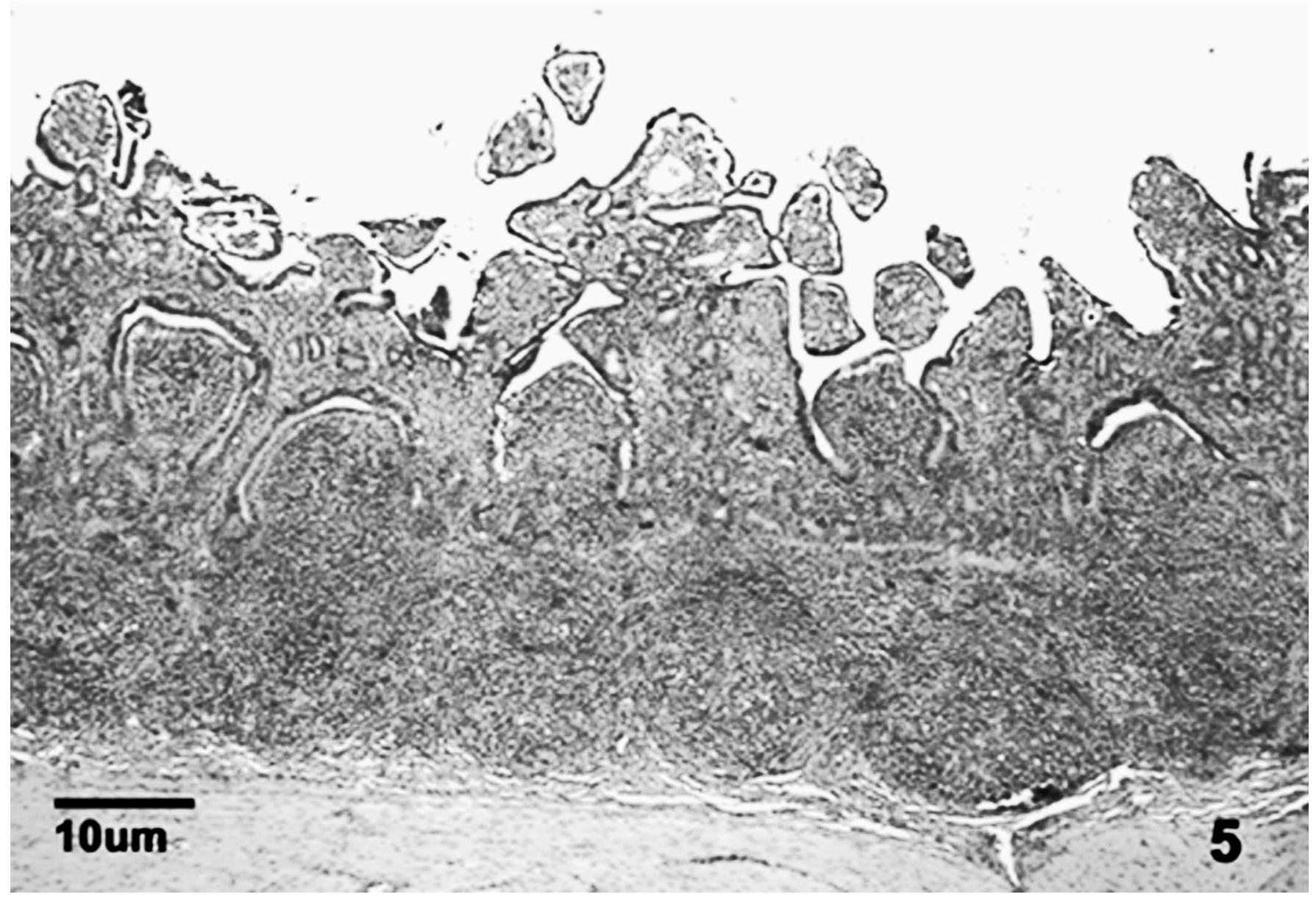

Figure 5. Section of ileum from dog AIZ infected with $1 \times 10^{5}$ Cystoisospora canis oocysts 10 days previously. Note mild villous atrophy, dilated lacteals, and marked lymphoid hyperplasia of the Peyer's patches.

nicity of $C$. canis oocysts in the present study are more similar to what was reported by Nemeséri (1960), rather than what was reported by Lepp and Todd (1974).

The present study demonstrated that $C$. canis is a primary pathogen in young dogs. Our histological studies demonstrated lesions (Fig. 5) in the small intestine, which were associated with the presence of developmental stages (Figs. 1-4) of $C$. canis and clinical signs of diarrhea. Bleach treatment of the inoculum rendered it free of bacteria, indicating that bacteria were not responsible for causing the clinical signs. Our attempts to demonstrate pathogenic bacteria and viruses in the 2 experimentally infected dogs examined at necropsy were negative, indicating that the coccidia were responsible for the clinical signs and microscopic lesions in these animals.

Solid immunity follows a primary $C$. canis infection, and no oocysts are discharged after challenge (Becker et al., 1981). We used young (6- to 8-wk-old) dogs in hopes of obtaining them before they developed a natural $C$. canis infection. Fortunately, none of our dogs came infected with $C$. canis because preinoculation fecal examinations for $C$. canis were negative and the timing of the prepatent period was consistent with the literature (Nemeséri, 1960; Lepp and Todd, 1974; Levine and Ivens, 1981). Prior infection is always a problem when working with coccidia in animals. Some of our dogs harbored C. ohioensis- like oocysts in their feces before infection (Tables I-III). However, this $C$. ohioensis-like infection did not prevent these dogs from being infected with $C$. canis nor did it preclude them from developing clinical signs. Neither of the 2 dogs used for microscopic lesion studies had prior infection with C. ohioensislike coccidia.

\section{ACKNOWLEDGMENTS}

These studies were supported by grants from Bayer HealthCare Animal Health to D.S.L. and A.M.Z.

\section{LITERATURE CITED}

BANDONI, S. M., AND D. W. DusZYNSKI. 1988. A plea for improved presentation of type material for coccidia. Journal of Parasitology 74: 519-523.

BeCKer, C., J. HeIne, AND J. Boch. 1981. Experimentelle Cystoisospora canis- und $C$. ohioensis-infectionen beim Hund. Tierärtliche Umschau Zeitschrift für Gebiete der Veterinärmedizin 36: 1-8.

Biester, H. E., AND C. Murray. 1934. Studies in infectious enteritis of swine, VIII. Isospora suis n. sp. in swine. Journal of the American Veterinary Medical Association 85: 207-219.

Boch, V. J., E. Göbel, J. HeINe, AND M. ERBER. 1981. Isospora-Infektionen bei Hund und Katze. Berl Munch Tierarztl Wochenschr 94: 384-391.

Correa, W. M., C. N. M. Correa, H. Langoni, O. A. Volpato, and 
K. Tsunoda. 1983. Canine isosporosis. Canine Practice 10: 44 46.

Daugschies, A., H. C. Mundt, And V. Letkova. 2000. Toltrazuril treatment of cystoisosporosis in dogs under experimental and field conditions. Parasitology Research 86: 797-799.

DuBEY, J. P. 1975a. Isospora ohioensis sp. n. proposed for I. rivolta of the dog. Journal of Parasitology 61: 462-465.

. 1975b. Experimental Isospora canis and Isospora felis infection in mice, cats, and dogs. Journal of Protozoology 22: 416-417.

.1978a. Life cycle of Isospora ohioensis in dogs. Parasitology

77: $1-11$.

1978b. Pathogenicity of Isospora ohioensis infection in dogs. Journal of the American Veterinary Medical Association 173: 192 197.

. 1979. Life cycle of Isospora rivolta (Grassi, 1978) in cats and mice. Journal of Protozoology 26: 433-443.

- 1982. Induced Toxoplasma gondii, Toxocara canis, and Isospora canis infections in coyotes. Journal of the American Veterinary Medical Association 181: 1268-1269.

- R. FAYER, AND F. M. SeEseE. 1978. Sarcocystis in feces of coyotes from Montana: prevalence and experimental transmission to sheep and cattle. Journal of the American Veterinary Medical Association 173: 1167-1170.

, AND J. L. MAHRT. 1978. Isospora neorivolta sp. n. from the domestic dog. Journal of Parasitology 64: 1067-1073.

, AND H. MEHLHORN. 1978. Extraintestinal stages for Isospora ohioensis from dogs in mice. Journal of Parasitology 64: 689-695. , S. E. Weisbrode, AND W. A. Rogers. 1978. Canine coccidiosis attributed to an Isospora ohioensis-like organism: A case report. Journal of the American Veterinary Medical Association 173: 185 191.

Dunbar, M. R., AND W. J. Foreyt. 1985. Prevention of coccidiosis in domestic dogs and captive coyotes (Canis latrans) with sulfadimethoxine-ormetoprim combination. American Journal Veterinary Research 46: 1899-1902.

Hayat, M. A. 1989. Principles of electron microscopy. 3rd ed. CRC Press, Boca Raton, Florida, 325 p.

Hilali, M., A. Fatani, And S. Al-Atiya. 1995. Isolation of tissue cysts of Toxoplasma, Isospora, Hammondia and Sarcocystis from camel (Camelus dromedarius) meat in Saudi Arabia. Veterinary Parasitology 58: 353-356.

, F. A. Ghaffar, And E. Scholtyseck. 1979. Ultrastructura study of the endogenous stages of Isospora canis (Nemeséri, 1959) in the small intestine of dogs. Acta Veterinaria Academy Science Hungary 27: 233-243.

, A. M. NASSAR, And A. El-Ghaysh. 1992. Camel (Camelus dromedarius) and sheep (Ovis aries) meat as a source of dog in- fection with some coccidian parasites. Veterinary Parasitology 43: $37-43$.

Junker, K., AND D. J. Houwers. 2000. Diarrhea, pup mortality and Cystoisospora species (coccidiosis). Tijdschrift voor diergeneeskunde 125: 582-584

KIRKPATRICK, C. E., AND J. P. Dubey. 1987. Enteric coccidial infections Isospora, Sarcocystis, Cryptosporidium, Besnoitia, and Hammondia. Veterinary Clinics of North America: Small Animal Practice 17: $1405-1420$.

LEPP, D. L., AND K. S. TODD, JR. 1974. Life cycle of Isospora canis Nemeséri, 1959 in the dog. Journal of Protozoology 21: 199-206. , AND - 1976. Sporogony of the oocysts of Isospora canis. Transactions of the American Microscopical Society 95: 98-103.

LEVINE, N. D., AND V. IVENS. 1981. The coccidia parasites (Protozoa: Apicomplexa) of carnivores. Illinois Biological Monographs 51. University of Illinois Press, Urban, Illinois, $248 \mathrm{p}$.

Lindsay, D. S., W. L. Current, and J. V. ERnst. 1982. Sporogony of Isospora suis Biester, 1934 of swine. Journal of Parasitology 68: 861-865.

- AND J. P. DUBEY. 1989. Immunohistochemical diagnosis of Neospora caninum in tissue sections. American Journal of Veterinary Research 50: 1981-1983.

, J. P. Dubey, And B. L. Blagburn. 1997. Biology of Isospora spp. from humans, nonhuman primates, and domestic animals. Clinical Microbiology Reviews 10: 19-34.

, B. P. Stuart, B. E. Wheat, and J. V. Ernst. 1980. Endogenous development of the swine coccidium, Isospora suis Biester 1934. Journal of Parasitology 66: 771-779.

Loveless, R. M., AND F. L. ANDERSON. 1975. Experimental infection of coyotes with Echinococcus granulosus, Isospora canis, and Isospora rivolta. Journal of Parasitology 61: 546-547.

MAHRT, J. L. 1967. Endogenous stages of the life cycle of Isospora rivolta in the dog. Journal of Protozoology 14: 754-759.

NeMESÉRI, L. 1960. Beitrage zur aetiologie der coccidiose der Hund, I: Isospora canis n. sp. Acta Veterinaria Academy Science Hungary 10: 95-99.

Penzhorn, B. L., K. G. De Cramer, and L. M. Booth. 1992. Coccidial infection in German Shepherd dog pups in a breeding unit. Journal of the South African Veterinary Association 63: 27-29.

Rommel, M., AND B. ZiELASKO. 1981. The life cycle of Isospora burrowsi (Trayser and Todd, 1978) in the dog. Berliner und Münchener Tierärztliche Wochenschrift 94: 87-90.

Trayser, C. V., AND K. S. TODD, JR. 1978. Life cycle of Isospora burrowsi n sp (Protozoa: Eimeriidae) from the dog Canis familiaris. American Journal of Veterinary Research 39: 95-98.

Zayed, A. A., AND A. El-Ghaysh. 1998. Pig, donkey and buffalo meat as a source of some coccidian parasites infecting dogs. Veterinary Parasitology 78: 161-168. 